\title{
Determination Of $\beta$ - Carotene from Local Vegetables: Zogale Leaf Moringa Oleifera, Red Sorrel Calex Herbiscus Sabdarifa and Dinya Leaf Vitex Doniana
}

\author{
John Ochola Idoko \\ Department of chemistry, Collage of science, Federal University of Agriculture and centre for Agrochemical \\ Research, PMB 2373, Makurdi-Nigeria.
}

\begin{abstract}
The determination of $\beta$-carotene was carried out by solvent extraction, these solvent includes, petroleum spirit and ethanol and the absorbance measured with a spectrophotometer (spectronic min 20) @ $480 \mathrm{~nm}$ with molar extinction co efficient of 2.23. $\beta$-carotene levels of the various vegetables were found to be; Zogale Moringa oleifera with $\beta$-carotene level of $0.18 \pm 0.0013 \mathrm{mg} / \mathrm{L}$, Dinya Vitex doniana $0.17 \pm 0.0024$ and Red sorrel Herbiscus sabdarifa $0.17 \pm 0.0014 \mathrm{mg} / \mathrm{L}$, $\beta$ From the results as indicated the various levels of $\beta$-carotene content is a good indication that, these local vegetable if taken, will correct abnormally derived from the lack of vitamin ' $A$ '
\end{abstract}

Keywords: $\beta$-carotene, Spectrophotometer, Zogale, Dinya, red sorrel.

\section{Introduction}

The prevalent symptoms amongst the infant age leading to the adulthood in areas of growth, good eyesight, maintenance of the moist surface tissues is a major health problem challenging the world in recent time. Research as traced it to lack of vitamin in the diet possible vitamin 'A'. Attention is focused on the incidence of deficiency diseases, and the recognizable symptoms of which may be attributed to lack of some particular nutrients on the basis that has to do with problem of good sight, growth regulations which ranges from infant to adulthood. These is common to people with vitamin A deficiency. Pro vitamin ' $\mathrm{A}$ ' is any several compound chemically related to vitamin ' $A$ ' that are readily converted in the body to active vitamin ' $A$ '. $\beta$ Carotene occurs in plant as a precursor to vitamin 'A'. It is a pro vitamin A, a yellow red pigment found especially in carrot, yellow corn sweet potato, vegetables leaves, peaches, fresh pear, milk, liver, spinach, amongst others. Examples of carotenoids includes; - $\quad \beta$-carotene, $\gamma$-carotene etc. [1]

The development of the knowledge as to the relationship between vitamin 'A' and carotenoids and as well as their chemical nature, represent a highly interesting chapter of vitamin research which illustrate the course of such studies. In 1914, Mcollom and Davis found that vitamin was contained in the un saponified fraction of milk fat and later studies confirmed its identity as an unsaponifiable constituent extractable by lipid solvents [2]. In 1919, Steembock called attention to the fact among vegetable food vitamin 'A' potency was associated in a rather remarkable way with yellow colour. Shortly, he and his associate published many data demonstrating the extraction procedures. They went as far as to suggest that carotene was the source of vitamin ' $A$ '. This view was not accepted by some researcher, and Steembock came to recognized that vitamin was not carotene itself, because certain potency source of vitamin were colourless. Ten years later the riddle was solved [3]. Von Euler and associate in Stockholm obtained a definite growth response when carotene was added to vitamin 'A' deficient diet. Carotenes are known,

Determination of $\beta$ - carotene from local vegetables: Zogale leaf Moringa oleifera, red sorrel calyx Herbiscus sabdarifa and Dinya leaf Vitex doniana

the most important is $\beta$-carotene which is often refers as pro vitamin A. $\beta$-carotene is a red solid which was first isolated from carrot indeed it was yellow in colour, which is often used to colour margarine the molecule of $\beta$-carotene is almost exactly twice as big as that of vitamin ' $A$ ', but it is a hydrocarbon not alcohol and has the structure shown below,[4]

In 1929, Moore produced proof that animal body transform $\beta$-carotene into vitamin $\mathrm{A}$, he fed rat on a diet which resulted in the symptoms of deficiency, some of the animal were then killed and there livers found to be devoid of vitamin A. The rest of the animals were fed with carotene with a resulting disappearance of the deficiency symptom and on autopsy there liver were found to be rich with vitamin ' $A$ '. Meanwhile, habitat liver oil has been found to be a concentrated source of vitamin, and a fractional method was used to isolate the active substance [5]. These methods brought success in 1932, in the isolation by Karrer and his associate in the Switzerland and Drummond and his coworkers in England, [6]. Of a very active fraction which was identified as an unsaturated alcohol having the formula $\mathrm{C}_{2} \mathrm{OH}_{3} \mathrm{O}$. Marrer proposed the structural formula in which $\beta$-carotene shows the unsaturated side chain. The carotenoids do not have any vitamin activities but are converted into 
vitamin $\mathrm{A}$ in the liver or the wall of the small intestine. Amongst all the carotenoids, $\beta$-carotene is the most efficient precursor to vitamin ' $\mathrm{A}$ ', this is due to its symmetrical molecules which give rise to two molecules of vitamin A, [7]. Carotenes generally are however poor source of vitamin A, this is due to its inability to be completely absorbed. Vitamins are organic substances which have to be taken by organism in trace amount to enhance proper physiological and Biochemical function of the tissues. The diet is obviously the main source of vitamins, but in some cases, there are contributions from the bacteria which exist symbiotically in the gut. The intake is necessary because the body cannot produce these substances at least not in sufficient amount at all times, [8].

The aim of this study is to determine the $\beta$-carotene content in these local vegetables, Zogale (Moringa oleifera), Dinya (Vitex doniana) and Red sorrel (Herbiscus sabdarifa). The need for every farmer to have vital idea of the nutritive value of the locally grown vegetables in the area where these vegetables' are mostly grown .Special attention is derived from the need to know the right proportion to be taken in terms of the vitamin contents. In as much as the lack of vitamin ' $A$ ' is adversely on man resulting from night blindness to total blindness and other resulting symptoms, keratinization of the epithelia membrane of the skin etc,[9]. Nutritional supplement of vitamin 'A' could be derived from relatively cheap sources of these locally grown vegetables which goes a long way in reducing these effect. Since vegetables and grain contains no vitamins 'A' as such, but pigments categorized as carotenoids which are easily converted to vitamin ' $A$ '. Estimate was made based on the presence of these precursors (pro vitamin 'A'). Appropriate conversion factor could be used to equate the equivalence of vitamin A in each sample, but this will not be determined in this studies. Several carotenoids may give same spectrophotometric readings with $\beta$-carotene in particular, since all carotenoids are normally found together, separation may be achieved by more sophisticated analytical techniques, such as chromatographic techniques for separating them into different component before further estimation could be made for accurate results and identifications, [10]. This study is limited to the determination of $\beta$-carotene, a precursors to vitamin 'A' an important of all carotenoids, by solvent extraction method using spectrophotometer.

Determination of $\beta$ - carotene from local vegetables: Zogale leaf Moringa oleifera, red sorrel Calyx Herbiscus sabdarifa and Dinya leaf Vitex doniana

\subsection{Sample Collection}

\section{Materials and Methods}

The leaves of Zogale, Dinya and red sorrel calyx were all collected from the farm in the University of Agriculture Makurdi-Nigeria, and were washed with distilled water to remove any sand particles. It was later put in the mortar and was macerated to increase the surface area for adsorption to take place.

\subsection{Reagents}

Reagent for this research work are all in analytical grades, they includes, Absolute ethanol 99\%, (BDH chemicals limited England) petroleum spirit, (BDH chemicals limited England), and distilled water, all from the postgraduate research laboratory, Federal University of Agriculture Makurdi-Nigeria.

\subsection{Equipments}

Spectrophotometer,( spectronic mini 20 ATAC Czechoslovakia ),Electric heating water bath,(EL-20 SKLO uninlabora praqune Czechoslovakia), Analytical weighing balance Adam equipment co Ltd uk ,measuring cylinder, separating funnels, , conical flask, beakers, $250 \mathrm{~mL}$ volumetric flask, retort stand, funnels mortar and pistil etc.

\subsubsection{Sample Analysis}

Separate $10 \mathrm{~g}$ of finely macerated Zogale, Dinya leaves and red sorrel calyx was extracted in $100 \mathrm{~mL}$ of hot ethanol for $30 \mathrm{~min}$, with occasional shaking. The ethanol extract was put in a beaker and placed in a hot water bath, to increased the surface area. The samples extract was decanted and distilled water was added to bring their respective volume to $85 \%$ ethanol [2].

The warm ethanol extract was allowed to cool at room temperature, after cooling it was shaken with $30 \mathrm{~mL}$ of petroleum spirit in a separating funnel, the bottom layer was run into separate beakers and the top petroleum spirit layer was put into another beaker. The bottom ethanol extract was returned back to the separating funnel and was re extracted with the petroleum spirit and these was done repeatedly.

The petroleum spirit extract that contains the extracted carotenoids was returned to the separating funnel where $50 \mathrm{~mL}$ of the $85 \%$ ethanol was added and shaken as in the first stage of extraction with the petroleum spirit. The lower layer of the mixture was run off to remove any xanthophylls that may have escaped into the petroleum spirit during the process, these procedures was carried out in triplicate and extract was ready 
to be analysis for $\beta$-carotene with spectrophotometer at $480 \mathrm{~nm}$.Concentrions of each sample were gotten using Bear's equation [11].

Determination of $\beta$ - carotene from local vegetables: Zogale leaf Moringa oleifera, red sorrel Calyx Herbiscus sabdarifa and Dinya leaf Vitex doniana

\section{Results and Discussion}

Results of the analysis indicates that $\beta$-carotene levels in Zogale Moringa oleifera, Dinya Vitex doniana and Red sorrel Vitex doniana is given as follows:- Zogale, $0.18 \pm 0.013$, Dinya $0.17 \pm 0.0024$ and Red sorrel $0.17 \pm 0.0014$ as shown in Table 1 was calculated using Bear Lambert law and mean standard deviation to calculate the various concentration of $\beta$-carotene levels in these vegetables.

Table $1 \beta$-carotene levels in Zogale, Dinya and Red sorrel.

\begin{tabular}{ll}
\hline Name of Samples & Mean Levels of $\beta$-carotene $\mathrm{mg} / \mathrm{L} \mathrm{95 \%}$ \\
& $\mathrm{CL}$ \\
\hline Zogale Leaves & $0.18 \pm 0.013$ \\
Dinya Leaves & $0.17 \pm 0.0024$ \\
Red sorrel calyx & $0.17 \pm 0.0014$ \\
\hline
\end{tabular}

From the above "Table," it is observed that $\beta$-carotene level of Zogale Moringa oleifera is higher with $0.18 \pm 0.013 \mathrm{mg} / \mathrm{L}$ at $95 \%$ confidence limit, followed by Dinya Vitex doniana with the second highest level with $0.17 \pm 0.0024 \mathrm{mg} / \mathrm{L}$, and Red sorrel Herbiscus sabdarifa with $0.17 \pm 0.0014 \mathrm{mg} / \mathrm{L}$ at $95 \%$ confident limit compared with $\beta$-carotene level of tomato, $0.17 \pm 0.0023 \mathrm{mg} / \mathrm{L} \mathrm{[2].} \mathrm{Hence,} \mathrm{these} \mathrm{various} \mathrm{levels} \mathrm{fall} \mathrm{within} \mathrm{the}$ acceptable limit of international standard. Geographical location, soil texture and growth condition for these vegetables may vary considerable. These conditions may also have effect on the availability of the presence of carotenoids in these locally grown vegetables, which makes the efficiency of retinol production varies amongst types.

\section{Conclusion}

From all indications $\beta$-carotene levels in these locally grown vegetables are within the acceptable limits and limits of possible experimental and instrumental error, these results of the entire experimental analysis is a good indication of the $\beta$-carotene levels in the respective samples, and the need for the production of these locally grown vegetables should not be over emphasized due to its nutritional attributes to man.

\section{Acknowledgment}

Author is thankful to the entire staffers of the advance chemistry laboratory of the federal University of agriculture Makurdi-Nigeria for there support during the bench work

Determination of $\beta$ - carotene from local vegetables: Zogale leaf Moringa oleifera, red sorrel Calyx Herbiscus sabdarifa and Dinya leaf Vitex doniana

\section{References}

[1]. Mushstaq A. [1998] The essential of Medical Biochemistry, volume II $6^{\text {th }}$ edition, page 101-103.

[2]. Pearson S. [1976] Chemical analysis of foods, $3^{\text {rd }}$ edition, page 96-100.

[3]. Tindall HD [1996] Commercial vegetables growing London, Oxford University press.

[4]. Monica J.C and Ford G.C [1997] Chemical analysis of foods and Beverages, a university journals, page 46-61

[5]. Allen SE, Grimshaw H M, Rowland AP. [1986] Chemical analysis. In: Moore, PD, Chapman, SB. (Eds.), Methods in Plant Ecology, Blackwell Scientific Publication, Oxford, London, pp. 285-344.

[6]. Makker G. and Beaker M. [1997] Nutritional Science for university colleges, $6^{\text {th }}$ edition page 45,47 and 50 .

[7]. Afolayan G.G [2003] Statistical and experimental design. A hand book for tertiary education, page 36.

[8]. Haruna A. and Charles N [2005] Biochemistry practical manual, Volume 1.page 65-69

[9]. American Society for Testing and Materials,(1995). "D-4793, 1994. Standard Test Extraction of Waste with Water.” Annual Book of ASTM Standards, Vol. 11.04, pp. 58-67.

[10]. Vogel, A.I, Mendham J. Denny j. Thomas J. and Barnes J D (2000). A Text Book of Quantitative Chemical Analysis, (6th ed.). ELBS, London. Pg 430-440 